\title{
The Shroud and the Trope: Representations of Discourse and of the Feminine in Homer's Odyssey
}

\author{
Alexandre Veloso de Abreu \\ Pontifical Catholic University of Minas Gerais, Minas Gerais, Brazil
}

\begin{abstract}
Understanding that Homer's Odyssey (1998) has a feminine perspective, this paper intends to explore the Greek epic placing queen Penelope as the protagonist, observing, mainly, the narratological shifts in the story grammar, duration and character elaboration. This study also uses Paul Ricoeur's The Rule of Metaphor (2008) to analyze the episode of the shroud in Homer's Odyssey. Ricoeur sees metaphor in three distinct levels: the level of lexis where he bases himself in the works of Aristotle; the level of phrase in which he recurs to the structuralist linguistician Émile Benveniste; and the metaphor in the level of discourse, when Ricoeur himself devises an elaborate study of the figure of speech. Penelope's weaving can be understood as a representation of discourse and of the feminine. Such analogy transcends the stereotype she is often given and defines a new role for the character in the epic.
\end{abstract}

Keywords: narratology, genre, feminine, Penelope, classical literature

\section{Introduction}

If we acknowledge John Finley's (1978) explanation in Homer's Odyssey that "Penelope is the central figure of home; she both kept it in existence and makes it recoverable" and that the main theme of the epic is not the nostos like Aristotle believed but "life brought home, therefore finally shared" (p. 4), we can understand why the same Finley considers that the Odysseia could also be called Penelopeia.

Other Hellenists such as Bentley (1838) observe that, due to the themes, the Iliad (1998) was intended for a male audience and the Odyssey for a female one. Butler (1900) goes further: Heclaims that Nausicaa, the pheacian princess, would be, in fact, the one who tells us the story of Odysseus, because of the strong feminine appeal contained in the narrative.

Using narratology, it is possible to explore such considerations. According to Page (2006) in her study entitled: Literary and Linguistic Approaches to Feminist Narratology, it is possible to "reframe the description of 'male' and 'female' plots through the lens of narrativity" (p. 25). Narrativity is a narratological concept that deals specifically with narrative construction. It concentrates on progression of narrative, from its beginning to its end and how aspects such as time, space, conflict, duration, and character elaboration are presented. In a way, it is what makes a text, a narrative. Monica Fludernik (2009) clarifies that "traditionally, narrativity is defined in terms of plot, the minimal definition being: the presence of at least two actions or events in chronological order which stand in some kind of relation to one another" (p. 150).

Alexandre Veloso de Abreu, Ph. D., Department of Linguistics and Literature, Pontifical Catholic University of Minas Gerais. 
Various strategies intensify the narrativity of a story. More traditional ones such as fables and epics tend to have a more linear chronology and progression action, therefore a more complex narrativity. The more the narrative subverts canonical elements of narrative such as time, space and duration, the less narrativity it contains. Nonetheless, one should not confuse narrativity with complexity. As a matter of fact, novels with low narrativity tend to demonstrate high complexity in style. Let us focus on some of these aspects understanding Penelope as the protagonist.

\section{Adventures in the Megáron}

Penelope definitely plays a fundamental role as a character in Homer's Odyssey. We can even perceive the entire development of the narrative focusing Penelope as the "dramatis persona". To understand the condition of Penelope's protagonism a parallel will be made with the actions executed by her husband, essential figure of the epic. Every great deed performed by Odysseus has an equivalent one executed by Penelope. We can say that if Penelope is not the "dramatis persona" herself, she at least shares the same level of protagonism of the Greek hero.

It is true that Penelope's dislocation is restricted to the Megáron, which in a Proppian perspective would already unable the queen to be the protagonist, for she must initiate a voyage that would suppose leaving the realm of Ithaca, but I will consider the palace as a major adventure place, where the mobilization of the character requires a full detachment of the concept of the Megáron. A household does not have to be necessarily a space of passivity and recollection. We will notice that Penelope becomes restricted to the gynoecium after the suitors take over the Herkeios and other major chambers of the palace. Nonetheless, her cunning strategies allow the queen to be an active character.

The focus of this action will be on the shroud mainly, although we do understand that Penelope parallels Odysseus protagonism in various episodes. The table that follows compares the events that each character goes through, clarifying their equal importance in the epic (see Table 1).

Table 1

The Two Protagonists of the Odyssey

\begin{tabular}{|l|l|}
\hline Odysseus' Actions & Suitors (oikos) \\
\hline Ciconians (oikos) & Telemacusin Pylosand Sparta \\
\hline Lotophagous e Laestrygonians & Penelope deceives the suitors \\
\hline Odysseus deceives the Cyclopes & Antinous \\
\hline Circe & Dream with the geese \\
\hline Nekeuia & Phemius singer (song) \\
\hline Sirens(song) & Bow contest (ordeal) \\
\hline Scylla and Charybdis (ordeal) & Slave girls \\
\hline Cattle of the Sun & Eurymachus \\
\hline Calypso & \\
\hline
\end{tabular}

Odysseus' attack to the Ciconians makes him lose many men and a considerable amount of his war prizes. 
The suitors drain the king's property while waiting for Penelope's decision. The adventures of Odysseus with the Lotophagous and Lestrygonians remind us of Penelope's worries when Telemacus is abroad at Pylos and Sparta. Odysseus in courted by Circe and Calypso while Antinous and Eurymachus seem to be the most articulated suitors. Odysseus visits the ghosts from the underworld facing a "katabasis" and Penelope confronts her internal fears dreaming about the massacre of her pet geese. The Sirens' songs are of grief as well as the songs of the singer Phemius in the palace of Ithaca. Scylla and Charybdis synthesize Odysseus ordeals and the bow contest in Book XX Penelope's ones. All Odysseus' soldiers die after their excessive behavior concerning the cattle of the Sun and many slave girls lose their lives after betraying the queen. Penelope performs intense actions but the one involving the shroud enhances her abilities with discourse and will be considered her major heroic trait.

\section{The Shroud and the Trope}

Penelope's shroud is perhaps the most enigmatic object in Homer's Odyssey. In the primeval stage of writing, copyist wrote their texts on cloths, hence the Latin word textere to describe something registered on texture. From such lexicon derived the radical form text-, present in various Western languages, usually describing the act of writing itself. The fact that the product was literally written on a texture, and this texture was a confection, contributed to the close relation between discourse and weaving.

In Penelope's etymological background we see the radical $\boldsymbol{\pi} \eta \mathbf{v} \mathbf{\eta}$ which is the Greek term for shuttle, bobbin or distaff, as well as thread, wool or, even, fabric, cloth. Such devices were very common in Mycenaean Greece and are frequently described in Homeric narratives. Jenny Strauss Clay reminds us that the Ancient Greek names have a very literal meaning. Considering this assumption, we would have something like: action-of-the-thread or weaving-of-the-distaff as the meaning of Penelope. Although this a considered etymology, the most common one points out that Penelope derives from $\pi \eta \mathbf{\eta} \varepsilon \dot{\lambda} \mathbf{o} \boldsymbol{\psi}^{1}$, a type of wild duck; quite plausible if we consider that the queen of Ithaca is the daughter of the naiad Periboea.

Penelope's name already shows the many nuances of the tropos in the story and we can observe that metaphors are figures of speech immensely exploited in Greek Epics. Understanding the complexity of the metaphor as a narrative strategy, the author recurs to Paul Ricoeur's acclaimed The Rule of Metaphor (2008) to analyze the resourcefulness of the Homeric metaphor in the verses of the Odyssey, concentrating specifically on Penelope as a major representation of discourse and of the feminine.

Ricoeur sees metaphor in three distinct levels. First, he analyzes it in the works of Aristotle, mainly Poetics, to study the figure of speech in its lexis, a "word level"; Second, the structuralist linguistician Émile Benveniste is contemplated to illustrate the metaphor in its phrasal level. Ricouer concludes his study presenting the metaphor in a discourse level, its most complex and complete manifestation.

According to Ricoeur, Aristotle considers the metaphor as a transposition of a name to another name via analogy. Within the metaphor we face the intricate concepts of displacement, extension and substitution of the name. The major goal of this strategy would be persuasion, mainly in oral discourse and in tragic poetry.

\footnotetext{
${ }^{1}$ Didymus Chalcenterus reminds us that Penelope's original name was Ameirace, Arnacia, Arnaeaor Nauplia. Her parents rejected her and tossed her into the sea, where she drifted for days. She was aided by seabirds, hence the new name associated with ducks. This association still causes ambiguity.There is exuberance in theduck, as well as some sloppiness, a factor that helps to confirm a more enigmatic Penelope.
} 
We can observe the use of metaphors in Penelope's action in the Odyssey, described here by the suitor Antinous:

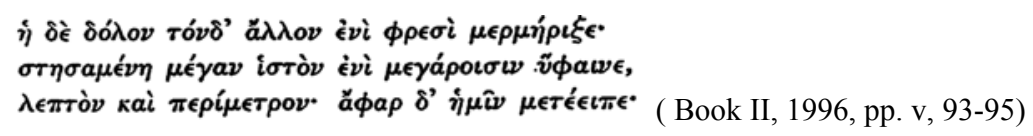

she set up a great loom in the royal halls

and she began to weave, and the weaving finespun,

the yarns endless, and she would lead us on....

The second verse literally says: "lifting a great loom". The vertical threads of the loom are called $\sigma \tau \eta \mu о v \varepsilon \varsigma$

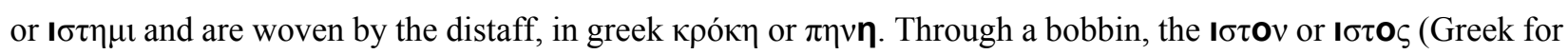
fabric), is made ${ }^{2}$.

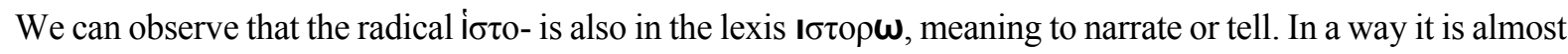
compelling to associate thread and story since both share the Greek radical, but the lexicon guides us to a more intricate relation, the fact that Penelope is stalling the suitors through the weaving and unweaving of her shroud.

The importance of the ruse of the web is evident. If we consider that Odysseus was gone ten years fighting in the war and took ten more to come back, the queen's plan to stall the suitors should have lasted at least four years, time necessary to maintain Ithaca in its amorphic state until the original king was back. In a way Penelope's action is similar to the one performed by the epic singer, even though she is weaving on texture, something that would remind us more of written discourse. Nonetheless, Penelope can undo her story and reinvent another one, just like the exercise performed by the oral singer. To weave and to narrate have the same implication. The warp and weft of the shroud deceived the suitors like the discourse in a fictional narrative, a simulacrum that can become as sublime as its idea. The ability of weaving and manipulating discourse is Penelope's heroic talent. She is, as her husband, a polytrópos, a person with discursive tricks.

Allegorically speaking the shroud can be considered a representation of written discourse, subtly woven to dialectally postpone the intention of the suitors. It reminds Odysseus deceiving the Cyclops. The hero tricks Polyphemus with a lexical/semantical pun, taking advantage of the monster's barbarism calling himself "Nobody" (Ovזı)).

Penelope also deceives the suitors with a representation of discourse, a texture that does not exist in fact. A texture that will not be seen, it is a shroud promised for Laertes but its completion was never the intention. That's the story, the fabulation. Deceived by the weaving and unweaving of the $\mathbf{\sigma} \sigma \mathbf{O} \zeta$, the suitors never notice that the real nature of discourse is to be rewritten or reinvented ${ }^{3}$. The reviving and the erasing of the tropos illustrate that discourse can never be narrated or interpreted the same way.

It is observed that Penelope transcends the divine act of the Muses and of the Morai. The daughters of

\footnotetext{
${ }^{2}$ The frame of the loom was not placed, as in modern looms, in a horizontal position, but stood upright. The threads of the warp hung perpendicularly down, and were drawn tight by weights at their lower ends. To set up the beam and so begin the web is

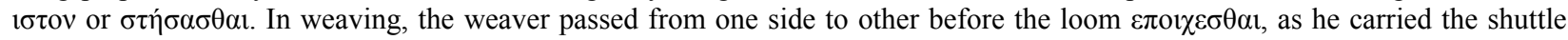

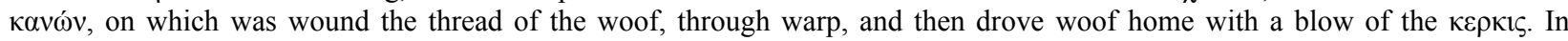
general we have weaver's beam, loom, warp, web, woven stuff for the meaning of $1 \sigma \tau$ ov (Autenrieth).

3 The shroud was undone during the night. Curious is that the suitors did not have access to gynoecium. Probably Penelope was aware that some of her maids sided with them, hence the fact that she actually had to weave the shroud she promised to Laertes. Nonetheless the dialectical purpose withstands for the maids reported to the suitors what Penelope was weaving.
} 
Memory do not register their songs; they rely on the singer to tell them, while the Fates weave the story of every being but cannot unweave their doing. Penelope demiurgically remakes what she weaves, narrates and unfolds her story magically. This magic is, in fact, what maintains Ithaca in lethargy so Odysseus can reclaim it.

Probably the shroud had a theme. We can infer that by the scene containing Helen's weaving in the Iliad. Usually the shroud contained an illustrated theme related to heroic deeds. Although it is not mentioned in the verses of the Odyssey, we can speculate about it. Being a present for Laertes, the web could have pictured his accomplishment in the Argonautica. Another possibility, the most accurate one, is that the queen was retelling the voyage of Odysseus himself. Both of them are metatextual, but if we understand that the shroud's theme is the voyage of Odysseus, Penelope is, together with the singer, participating of the entire retelling of the narrative. She does, though, undo what she is weaving, having to weave other versions, somewhat her actions are even more sophisticated than the ones performed by the singer. Metaphorically the texture executes the same act as the oral performance. What was woven would overcome memory, since it could be undone.

Many studies focus on Penelope's discursive ambiguity. Katz (1991) reveals an accented dissimulation of the character as does Felson-Rubin (1997), although more nuanced. The last author uses the Baktinian dialogic model of literary studies to carefully look at Penelope's interaction with other characters and verify her boldness. Clayton (2004) emphasizes the queen's use of weaving to demonstrate her cleverness, while Papadopoulou-Belmedi (1994) takes the strategy of unraveling the shroud as a "representation of the ambiguity of action through an endless reconfiguration of the shroud", there by Penelope is metaphorically remaking her own story. Penelope is shown here as cunning and dubious, but not in any way indeterminate. As for Heitman in Taking Her Seriously: Penelope and the Plot of Homer's Odyssey (2005), Penelope is seen as an independent thinker always maintaining her integrity, although the character does apply her tricks enhancing her indeterminate nature.

All of the studies mentioned here examine the acts of Penelope in a metaphorical sense. In Ricoeur's conception, it would be considered a metaphor in its discursive level. The philosopher understands that Language has infinite resources that enhance discourse in creative ways. The elaboration of metaphors and creation of narratives are genuine ways of vivid discourse confection.

The major debate in The Rule of Metaphor, centers itself "in the linguistic productive imagination that generates and regenerates meaning through the power of metaphoricity to state things in new ways" (Dauenhauer \& Pellauer, 2011). Ricoeur (2008) points out that new metaphors, ones that weren't reduced to commonplace, see referents in a new perspective. Metaphors transform language and are not only rhetorical ornaments.

It is understood that the figure of language has a genuine cognitive importance and is "untranslatable without remainder into literal language" (idem). The same happens to narratives and the act of narrating itself, where literature can take meaning to another level.

Apparently the shroud takes a larger dimension, standing for the expression and voice of Penelope, if taken in the perspective suggested by Ricoeur. The entire epic is an elaborate texture of the queen making a stand in the gynoecium, confirming her heroic status in the narrative.

Since the beginning Odysseus is aided by the goddess Athena. This is not hard to understand in a metaphorical sense. The goddess of wisdom would obviously be inclined to help the most intelligent hero. In a way, all his cleverness is Athena manifesting her designated attributes. The same occurs with Penelope. It is 
known that Athena is the deity that protects the weavers and craftsmen. Therefore, Penelope is also blessed by the goddess ${ }^{4}$. The act of weaving, an exclusive woman's act in Ancient Greece, refers to the ability of Penelope to fabulate. The ability to master threads is equivalent to the one of mastering discourse. Allegorically the shroud is a representation of argumentation, dissimulation and misleading.

It is understood that Penelope transcends the Muses and the Fates, memory, and destiny, since she dominatesthe thread in its completion, the crux inepic narrative. Threads confection nets, the original act of entangling; weaving is the act of plotting, making points.Allegorizing the action of weaving via Penelope and associating it with speech and discourse is a discursive metaphor, considered by Ricoeur as a powerful tool in literature.

To elaborate on the importance of metaphor in the narrative of the Odyssey, two incidental stories are analyzed. Willcock (1998) usually understood these stories as mythological paradigms that associated the content of the story to something meaningful in the main narrative. These examples were inserted in a cyclical form linking the metadiegetical text with the main structure of the epic. Willcock himself devised some schematics, developing circular diagrams to illustrate his point.

Two paradigms involving Penelope are quite meaningful. The first one to be considered is retold by Penelope herself, while she is explaining her suffering to a disguised Odysseus. The queen of Ithaca elaborates on the myth of Aedona, having the suffering of a woman and mother as a main theme. It is a myth of origin, explaining the existence of the nightingale and how its song is associated with sadness. The daughter of Pandareus is envious of her sister in law Niobe, for she had had vast offspring while she bore an only child. Aedona devises a plan to kill Niobe's first born,Amareus. This hýbris makes her assassin her own son Itylus by mistake. After the excess, she prays to the gods to end her pain. She is then transformed in a nightingale, a bird that sings, according to the Greeks, the name of Itylus himself (Ití!Ití!). In fact, the Greek word for nightingale is aédon. The figure follows (see Figure 1):

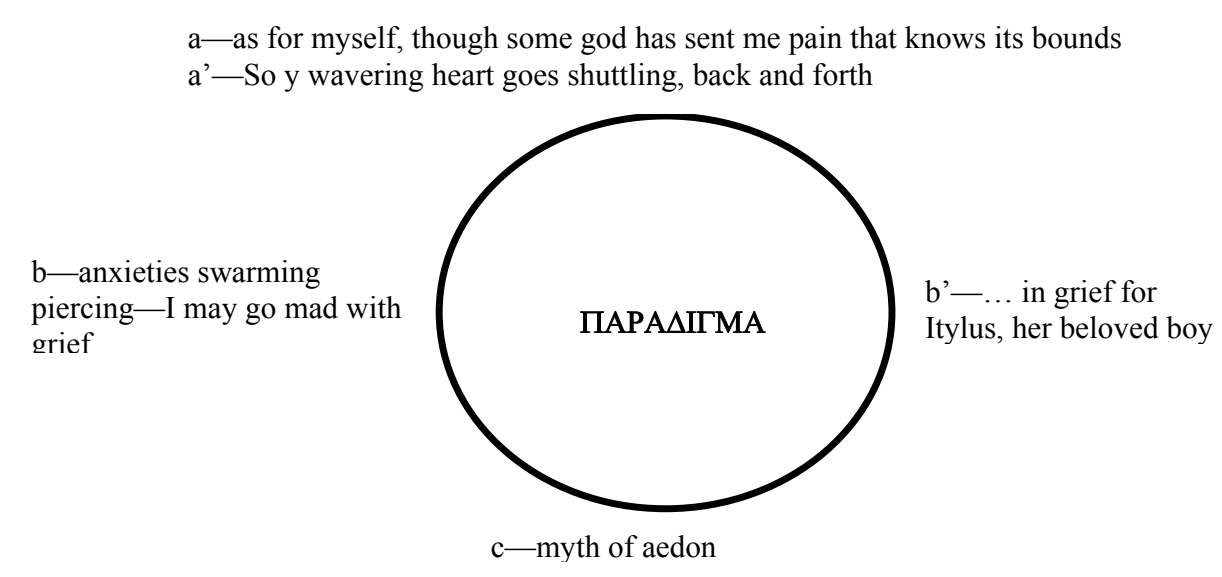

Figure 1. Paradigma 1.

\footnotetext{
${ }^{4}$ Athena is the patroness of the skill in weaving. While Hephaestus is concerned with the technai of men, Athena is associated with the craft in the life of women. Ovid's Metamorphoses contains a story that vividly shows the goddess performing this function, when she severely punishes the Lydian Arachne for having claimed that she was a better weaver than the diva herself. This myth metaphorically illustrates the use of weaving as an expression of feminine intellectual performance and how the power of the gods cannot be contested.
} 
Penelope begins describing how the sorrow of her husband's absence afflicts her. Such pain provokes her weeping, the element that links the main narrative to the story. The cry of Aedona is sad and varied, very similar to the crying done by Penelope. Weeping is the key word to leave the paradigm and come back to the homilia, the moment that Penelope in conversing with Odysseus. The myth is a metaphorical description of the queen's feeling at the moment and helps Odysseus understand the suffering Penelope has been through.

Another significant story is the myth involving the adultery of Aphrodite and Ares. The blind singer Demodocus tells us this adventure but, metaphorically, the example is associated with Penelope's fidelity. Again a figure is shown (see Figure 2):

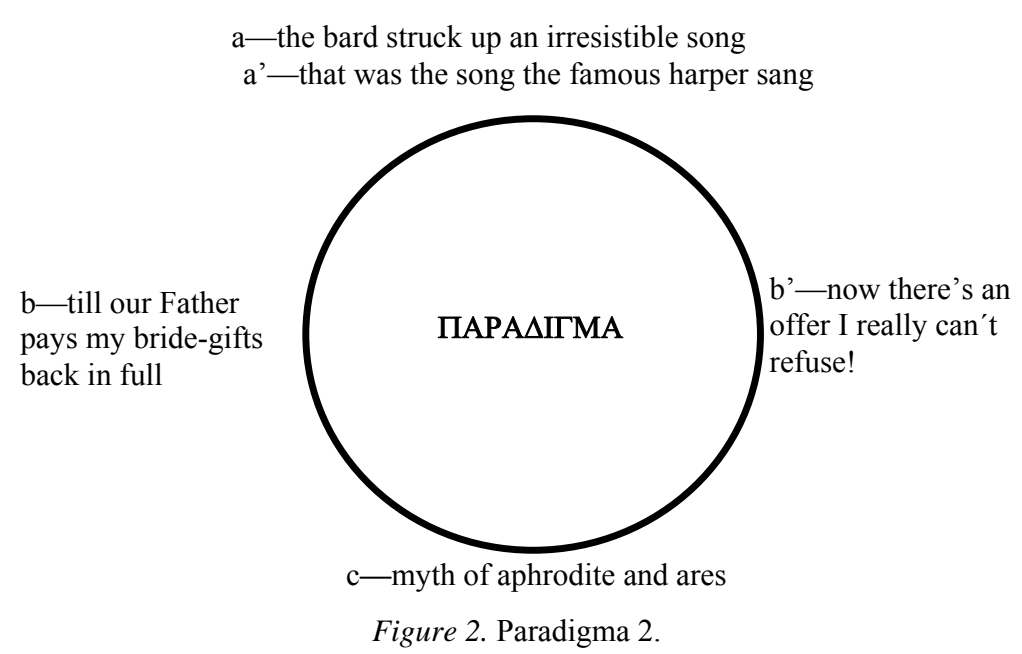

The myth retold by Demodocus is immediately associated with the plotline of the entire Odyssey. It is interesting to see a story that tells one of the most remarking cases of adultery in Greek Mythology being addressed to Odysseus. It is an allusion or a prolepsis to the greatest of challenges that is yet to come. More than regaining his kingdom dwells the fact if his most beloved wife remained faithful all these years. The myth also enhanced Penelope's perseverance and how her integrity is one of her most celebrated traits. The actions of Aphrodite have a consequence and the paradigm illustrates how this can be disastrous if an ethos is not followed. The story is a reminder of the delicate situation Odysseus may be facing at Ithaca. Penelope's condition appears in both these paradigms. The sad condition of Aedon confirms her depression and the story containing Aphrodite and Ares celebrates one of the most valued traits of the demigod: fidelity.

Smaller units of the story metaphorically translate the major theme of the epic narrative. The story grammar of the Odyssey can be perfectly understood as the maintenance of Ithaca as a realm belonging to the Laertiades and issues including Penelope are major issues for the development of the story.

Penelope's trope is what narrates the Odyssey, understood as a story about a great return, an epic of recognition. Odysseus says it himself:

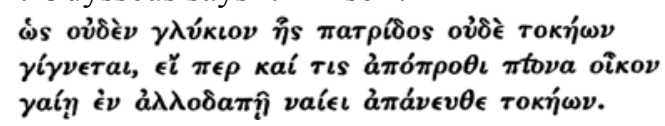

Mine is a rugged land but good for raising sonsAnd I myself, I know no sweeter sight on earth Than a man's own native country.
(Book IX, 1996, pp. v, 34-36) 
We are aware that the hero only has a home to call his own because of his wife's actions, metaphorically weaving her husband's return to his identity and being the major theme of one of the most celebrated canons of Western literature.

\section{Conclusions}

Hopelessly, the herostruggles justto understandthat itisimpossible tofully know everything and that you must go through an intense adventure to notice so. As for Penelope, her anagnórisis had already been accomplished and she ensures this by mastering the thread.

The Odyssey is introduced mentioning the house of Mycenae and of Ithaca. The attitude queen Clytemnestra and her lover Aegistus had is brought to light by Zeus himself. Helen's sister confirms her tragic destiny by killing her husband with her lover and triggering fate to a sad disclosure: being killed by her own son, Orestes. On the other hand, Penelope unweaves, unravels, deconstructs, and disconcerts her mantle, avoiding a tragic end. She is the Ur-weaver of an irresolvable narrative that will originate a genre of dialogism and polyphony. Betrayedby one of themaids, she eventually had to end her story, but her original intent was always to weave and unravel her thread again and again.

\section{References}

Aristóteles. (1993). Poética (Poetics). (Eudoro de Souza, Trans.). São Paulo: Ars Poética.

Autenrieth, G. (2000). A Homeric dictionary for schools and colleges. (R. P. Keep, Trans.). Norman: University of Oklahoma Press. Bentley, R. (1838). Collected works. London: F. Macpherson.

Butler, S. (1900). The Odyssey rendered into English prose for the use of those who cannot read the original. London: A.C. Fifield. Clay, J. S. (1996). The wrath of Athena: Gods and men in the Odyssey. Lanham: Rowman and Littlefield Publishers.

Clayton, B. (2004). A penelopean poetics: Reweaving the feminine in Homer's Odyssey. Lanham: Lexington.

Dauenhauer, B., Pellauer, D., \& Ricoeur, P. (2011). The Stanford encyclopedia of philosophy (Summer Edition). E. N. Zalta (Ed.). Retrieved from http://plato.stanford.edu/archives/sum2011/entries/ricoeur/

Felson-Rubin, N. (1997). Regarding Penelope: From character to poetics. Norman: University of Oklahoma Press.

Finley, J. H. Jr. (1978). Homer's Odyssey. Cambridge, Massachusetts: Harvard University Press.

Fludernik, M. (2009). An introduction to narratology. (P. H. Greenfield, Trans.). London: Routledge.

Graves, R. (1992). The Greek myths (4th ed.). New York: Penguin Classics.

Heitman, R. (2005). Taking her seriously: Penelope and the plot of Homer's Odyssey. Ann Arbor: Michigan.

Heubeck, A., \& Hoekstra, A. (1990). A commentary on Homer's Odyssey (Volume II, Books IX-XVI). Oxford: Clarendon Press.

Heubeck, A., West, S., \& Hainsworth, J. B. (1990). A commentary on Homer's Odyssey (Volume II, Books IX-XVI). Oxford: Clarendon Press.

Homer. (1996). The Odyssey. (R. Fagles, Trans.). London: Penguin Group.

Katz, M. A. (1991). Penelope's renown: Meaning and indeterminacy in the Odyssey. Princeton: Princeton University Press.

Page, R. E. (2006). Literary and linguistic approaches to feminist narratology. Hampshire: Palgrave Macmillan.

Papadopoulou-Belmehdi, I. (1994). Le chant de Pénélope: Poétiquedutissageféminindansl'Odyssée (Penelope's song: Poetics of the feminine weaving in the Odyssey). Paris: Belin.

Ricoeur, P. (2008). The rule of metaphor: Multidisciplinary studies of the creation of meaning in language. (R. Czerny, Trans.). Toronto: University of Toronto Press.

Russo, J., Fernandez-galiano, M., \& Heubeck, A. (1990). A commentary on Homer's Odyssey (Volume III, Books XVII-XXIV). Oxford: Clarendon Press.

Stanford, W. B. (1996a). Odyssey of Homer I-XII. London: Bristol Classical Press.

Stanford, W. B. (1996b). Odyssey of Homer XIII-XXIV. London: Bristol Classical Press.

Willcock, M. M. (1998). A companion to the Iliad. Chicago: The University of Chicago Press. 